\title{
Alterations in $\beta$-catenin/E-cadherin complex formation during the mechanotransduction of Saos-2 osteoblastic cells
}

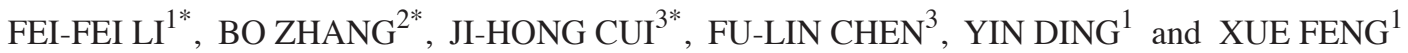 \\ ${ }^{1}$ State Key Laboratory of Military Stomatology, Department of Orthodontics, School of Stomatology; \\ ${ }^{2}$ Department of Pathophysiology, School of Basic Medical Sciences, The Fourth Military Medical University, \\ Xi'an, Shaanxi 710032; ${ }^{3}$ Laboratory of Tissue Engineering, Department of Biosciences, Faculty of Life Sciences, \\ Northwest University, Xi'an, Shaanxi 710069, P.R. China
}

Received February 20, 2017; Accepted October 24, 2017

DOI: $10.3892 / \mathrm{mmr} .2018 .9146$

\begin{abstract}
Mechanical load application promotes bone formation, while reduced load leads to bone loss. However, the underlying mechanisms that regulate new bone formation are not fully understood. Wnt/ $\beta$-catenin signaling has an important role in bone formation, bone growth and remodeling. The aim of the present study was to investigate whether mechanical stimuli regulated bone formation through the Wnt/ $\beta$-catenin signaling pathway. Saos-2 osteoblastic cells were subjected to mechanical strain using a Flexcell strain loading system. The results demonstrated that $12 \%$ cyclical tensile stress significantly stimulated Saos- 2 cell proliferation, increased the activity of alkaline phosphatase and promoted the formation of mineralized nodules, as determined by MTT and p-nitrophenyl phosphate assays and Alizarin Red S staining, respectively. Furthermore, western blot analysis demonstrated that, following mechanical strain, increased phosphorylation of glycogen synthase kinase-3 $\beta$ and nuclear $\beta$-catenin expression was observed in cells, compared with static control culture cells. Results of reporter gene and reverse transcription-polymerase chain reaction assays also demonstrated that mechanical strain significantly increased T-cell factor reporter gene activity and the mRNA expression of cyclooxygenase (COX)-2, cyclin D1, c-fos and c-Jun in Saos-2 cells. Co-immunoprecipitation analysis revealed that elongation mechanical strain activated $\mathrm{Wnt} / \beta$-catenin signaling and reduced $\beta$-catenin and E-cadherin interaction
\end{abstract}

Correspondence to: Dr Xue Feng or Dr Yin Ding, State Key Laboratory of Military Stomatology, Department of Orthodontics, School of Stomatology, The Fourth Military Medical University, 145 West Chang Le Road, Xi'an, Shaanxi 710032, P.R. China

E-mail: 421013470@qq.com

E-mail: fmmukqzjk@163.com

${ }^{*}$ Contributed equally

Key words: osteoblast, distraction osteogenesis, mechanical strain, $\beta$-catenin signaling, E-cadherin in Saos-2 cells. In conclusion, the results of the current study indicate that mechanical strain may have an important role in the proliferation and differentiation of osteoblasts. The disassociation of the $\beta$-catenin/E-cadherin complex in the osteoblast membrane under stretch loading and the subsequent translocation of $\beta$-catenin into the nucleus may be an intrinsic mechanical signal transduction mechanism.

\section{Introduction}

Bone is a dynamic tissue that undergoes continuous repair and remodeling throughout the lifetime of an individual $(1,2)$. The regulation of bone remodeling involves a balance between the number of osteoblasts and osteoclasts, which produce or resorb bone, respectively (3). Osteoblasts, osteocytes and osteoclasts are specialized cells that orchestrate the process of bone remodeling. As osteoblasts are highly sensitive to mechanical stimuli, these cells have the leading role in the bone remodeling process (4). It has been previously established that external mechanical stress, such as physiological levels of compression and tension force, induces the formation of new bone (5). Distraction osteogenesis (DO) is a bone regenerative response and is employed surgically to treat skeletal injuries and deformities (6). DO leads to the generation of new bone by applying tensile forces to the skeleton after a controlled osteotomy has been established (7). However, the mechanism by which the mechanical load is translated into intracellular signals remains unclear.

It is established that canonical Wnt signaling has an important role in the regulation of osteoblastogenesis and bone formation (8-10). Various studies have demonstrated that Wnt promotes osteoblast differentiation, proliferation and mineralization activity. The major component of the Wnt signaling pathway is $\beta$-catenin, which is a transcription factor and a structural adaptor protein that facilitates the binding of cadherins to the actin cytoskeleton during cell-cell adhesion $(11,12)$. Activation of Wnt signaling results in a loss of cadherin-mediated cell-cell adhesion and increased cytoplasmic $\beta$-catenin (13). $\beta$-catenin acts as a transcription cofactor with T-cell factor (TCF)/lymphoid enhancer-binding factor (LEF) in the Wnt pathway (14). Under normal conditions, $\beta$-catenin that is not associated with cadherins undergoes rapid 
phosphorylation by glycogen synthase kinase (GSK)-3 $\beta$, which targets it for degradation (15). However, upon phosphorylation of GSK-3 $\beta$, GSK-3 $\beta$-mediated phosphorylation of $\beta$-catenin is prevented, which leads to increased cytoplasmic levels of unphosphorylated $\beta$-catenin. Wnt signaling-induced cytoplasmic accumulation of $\beta$-catenin leads to increased entry of $\beta$-catenin into the nucleus and increased heterodimer formation with TCF/LEF transcription factors to regulate the expression of various Wnt target genes, such as cyclin D1 (16-19).

Previous studies have demonstrated that Wnt/ $\beta$-catenin signaling is involved in the early responses of osteoblastic cells to load bearing. The current study investigated the effects of mechanical strain on $\beta$-catenin in Saos-2 osteoblastic cells and investigated whether mechanical stimuli modulated $\mathrm{Wnt} / \beta$-catenin signaling.

\section{Materials and methods}

Saos-2 cell culture. The Saos-2 human osteosarcoma cell line (American Type Culture Collection, Manassas, VA, USA) was obtained from the Center Laboratory for Tissue Engineering, College of Stomatology, The Fourth Military Medical University (Xi'an, China) and used as osteoblasts (20). The cells were cultured in Dulbecco's modified Eagle's medium (DMEM; Gibco; Thermo Fisher Scientific, Inc., Waltham, MA, USA) supplemented with $10 \% \mathrm{v} / \mathrm{v}$ fetal bovine serum (FBS; Gibco; Thermo Fisher Scientific, Inc.) at $37^{\circ} \mathrm{C}$ in a humidified atmosphere of $5 \% \mathrm{CO}_{2}$ and $95 \%$ air. After reaching $90 \%$ confluence, the cells were detached by treatment with 10\% trypsin-EDTA (Sigma-Aldrich; Merck KGaA, Darmstadt, Germany) and cultured for $72 \mathrm{~h}$ on 6-well flexible-bottomed plates (type I collagen-coated BioFlex I plates at $37^{\circ} \mathrm{C}$; Flexcell International Corp., Burlington, NC, USA) at $1 \times 10^{5}$ cells per well. Subsequently, $10 \%$ FBS was replaced with $1 \%$ FBS prior to the application of strain force to cells. The $1 \%$ FBS provided minimal nutrition for the cells while allowing them to achieve a quiescent phase (G0). After $24 \mathrm{~h}$ starvation, the media was replaced again with DMEM containing 10\% FBS and cells were incubated for an additional $12 \mathrm{~h}$ at $37^{\circ} \mathrm{C}$. The plates were subsequently placed into the Flexcell's FX-4000T tension plus system (Flexcell International Corp.) in which the 6-well plates were docked.

Application of strain force. Flexcell's FX-4000T tension plus system (BF-3001U BioFlex ${ }^{\circledR}$ ) was used to generate cyclic tensile strain in the Saos- 2 cells. The instrument comprises a computer system controller and monitor, a control module that regulates negative and positive pressure, and a vacuum baseplate and gasket upon which the flexible-bottomed plates are placed (BioFlex I culture plates). Control of frequency, strain rate and degree of elongation of the deformation regimen are achieved by regulating the rate of evacuation (vacuum level) and rate of air influx to the plate bottoms. The flexible membrane with the adherent cells were subjected to cyclic, uniaxial strain at different magnitudes at a frequency of 1 cycle/sec $(\mathrm{Hz})$ along the long axis. Unstrained plates served as controls. Strain is the amount of deformation caused by an applied stress.

MTT analysis. Saos- 2 cells were subjected to 0 or $12 \%$ elongation by using Flexcell's FX-4000T tension plus system. At
$0,4,8$ and $12 \mathrm{~h}$ following loading, a $20 \mathrm{ml}$ sample of MTT solution ( $5 \mathrm{~g} / \mathrm{l}$ dissolved in PBS) was added to the culture plates and incubated at $37^{\circ} \mathrm{C}$ for $6 \mathrm{~h}$. The pipetted supernatant was discarded and $150 \mathrm{ml}$ dimethyl sulfoxide (Thermo Fisher Scientific, Inc., Waltham, MA, USA) was added to dissolve the blue MTT formazan produced by mitochondrial succinate dehydrogenase. The absorbance was measured at $492 \mathrm{~nm}$ in a spectrophotometer. The percentage of viable cells was calculated as the relative ratio of their absorbance to the control.

Biochemical alkaline phosphatase (ALP) assay. Biochemical analysis was employed to investigate the effects of different magnitudes of mechanical strain (as detailed above) on ALP activity. ALP activity was measured directly on the monolayer of the cultures. Following medium removal, cells were washed three times with PBS and shaken for $30 \mathrm{~min}$ at $37^{\circ} \mathrm{C}$ in $1 \mathrm{ml}$ saline buffer (PBS) containing $10 \mathrm{mM}$ p-nitrophenylphosphate (PNP; Sigma-Aldrich; Merck KGaA). PNP solution was removed and $1 \mathrm{ml} 1 \mathrm{~N} \mathrm{NaOH}$ was added to cells. The optical density was measured at $405 \mathrm{~nm}$. The ALP activity values were normalized to the relative number of viable cells, as determined using the proliferation assay described above.

Nodule formation and mineralization. Saos- 2 cells were treated with either 0 or $12 \%$ tensile stress for $8 \mathrm{~h} /$ day for 7 or 14 days. Mineralized nodule formation and the degree of mineralization were determined for osteoblast cultures cultured in 6-well plates using Alizarin Red S staining. Briefly, medium was aspirated from the wells and cells were rinsed twice with PBS. Cells were fixed with ice-cold $70 \% \mathrm{v} / \mathrm{v}$ ethanol for $1 \mathrm{~h}$. Ethanol was removed and the cells were rinsed twice with deionized water. Cells were subsequently stained with $40 \mathrm{mM}$ Alizarin Red S in deionized water (adjusted to $\mathrm{pH} 4.2$ ) for $10 \mathrm{~min}$ at room temperature. Alizarin Red $\mathrm{S}$ solution was removed by aspiration and the cells were rinsed five times with deionized water. Water was removed by aspiration and the cells were incubated in PBS for 15 min at room temperature on an orbital rotator. PBS was removed and the cells were rinsed once with fresh PBS. Mineralized Alizarin Red S-positive nodules present in each well were subsequently counted using light microscopy at magnification, $\mathrm{x} 40 ; 5$ fields of view were randomly selected per well.

Immunofluorescence. Immediately following treatment with $12 \%$ tensile stress for 0,4 or $8 \mathrm{~h}$, cells were prepared by washing with PBS and were immersion-fixed with $4 \%$ paraformaldehyde in PBS for $15 \mathrm{~min}$ at room temperature. Cells were subsequently permeabilized with $0.2 \%$ Triton-X-100 in PBS at room temperature for $5 \mathrm{~min}$. Then cells were blocked by $2 \%$ goat serum (OriGene Technologies, Beijing, China) at $37^{\circ} \mathrm{C}$ for $1 \mathrm{~h}$. Primary antibodies were diluted in PBS/5\% bovine serum albumin (Sigma-Aldrich; Merck KGaA). After rinsing three times with PBS, cells were incubated overnight at $4^{\circ} \mathrm{C}$ in a moist environment with a mixture containing primary antibodies against $\beta$-catenin (rabbit; 1:100; sc-7199; Santa Cruz Biotechnology, Inc., Dallas, TX, USA) and anti-E-cadherin (mouse; 1:100; sc-9988; Santa Cruz Biotechnology, Inc.), followed by incubation with a secondary antibody mixture containing Alexa Fluor ${ }^{\circledR} 594$ donkey anti-mouse IgG (1:500; 
Table I. Primer sequences used in semi-quantitative reverse transcription-polymerase chain reaction.

Primer

\begin{tabular}{|c|c|c|c|c|}
\hline \multirow[b]{2}{*}{ Gene } & \multicolumn{2}{|c|}{ Primer } & \multirow[b]{2}{*}{ Size, bp } & \multirow{2}{*}{$\begin{array}{c}\text { Annealing } \\
\text { temperature, }{ }^{\circ} \mathrm{C}\end{array}$} \\
\hline & Forward & Reverse & & \\
\hline$\beta$-actin & 5'-ATCATGTTTGAGACCTTCAA-3' & 5'-CATCTCTTGCTCGAAGTCCA-3' & 212 & 55 \\
\hline$\beta$-catenin & 5'-AAGGTCTGAGGAGCAGCTTC-3' & 5'-TGGACCATAACTGCAGCCTT-3' & 668 & 55 \\
\hline $\mathrm{COX}-2$ & 5'-TCAAGTCCCTGAGCATCTAC-3' & 5'-CATTCCTACCACCAGCAACC-3' & 488 & 58 \\
\hline Cyclin D1 & 5'-GAGACCATCCCCCTGACGGC-3' & 5'-СТСТTCСТCСТCCTCGGCGGC-3' & 484 & 56 \\
\hline$c-f o s$ & 5'-ACCAGTCCGGACCTGCAGTGG-3' & 5'-GCGGCATTTGGCTGCAGCCAT-3' & 261 & 57 \\
\hline c-Jun & 5'-CCCCTGTCCCCCATCGACATG-3' & 5'-TTGCAACTGCGTTAGCAT-3' & 267 & 55 \\
\hline
\end{tabular}

COX, cyclooxygenase.

R37115; Molecular Probes; Thermo Fisher Scientific, Inc.) and Alexa Fluor ${ }^{\circledR} 488$ donkey anti-rabbit IgG (1:500; R37118; Molecular Probes; Thermo Fisher Scientific, Inc.) for $2 \mathrm{~h}$ at room temperature. F-actin was additionally stained with Alexa Fluor ${ }^{\circledR} 350$ phalloidin (A22281; Molecular Probes; Thermo Fisher Scientific, Inc.) at a concentration of $7.5 \mathrm{U} / \mathrm{ml}$ for $30 \mathrm{~min}$ at room temperature, which was followed by washing three times with PBS. The cells were mounted on a drop of n-propyl gallate in $70 \%$ glycerol-PBS and viewed with a laser scanning confocal microscope (FLUOVIEW; Olympus Corporation, Tokyo, Japan) at magnification, x600 using FV1000 Viewer version 1.7a software (Olympus Corporation).

Reverse transcriptase-polymerase chain reaction (RT-PCR). Cells were subjected to 0 or $12 \%$ tensile stress for 0 or $4 \mathrm{~h}$. Cellular RNA was isolated from each culture using an RNeasy Mini kit (Qiagen, Inc., Valencia, CA, USA), according to the manufacturer's protocol. To remove contaminating genomic DNA, the RNA samples were treated with RNase-free DNase I (Qiagen, Inc.) at $37^{\circ} \mathrm{C}$ for $30 \mathrm{~min}$. Template RNA $(1 \mu \mathrm{l})$ was added to the individual tubes containing the master mix, using the Omniscript RT kit (Qiagen, Inc.). The tubes were centrifuged at $120 \mathrm{x} \mathrm{g}$ for $1 \mathrm{~min}$ at room temperature to collect residual liquid from the walls of the tube. The tubes were incubated for $2 \mathrm{~h}$ at $37^{\circ} \mathrm{C}$. RNase A $(2 \mu \mathrm{l} ; 10 \mathrm{mg} / \mathrm{ml})$ was added and the reaction mix incubated for $10 \mathrm{~min}$ at $65^{\circ} \mathrm{C}$ and then for $5 \mathrm{~min}$ at $93^{\circ} \mathrm{C}$ before being cooled immediately on ice. Subsequently, $1 \mu 1$ cDNA mixture was subjected to PCR amplification using specific primers. The primer sequences used in the current study are presented in Table I. Each PCR was performed in a $50 \mu \mathrm{l}$ mixture containing $1 \mu \mathrm{l} \mathrm{cDNA}, 5 \mu \mathrm{l} 10 \mathrm{X}$ Qiagen PCR buffer, $10 \mu 15 \mathrm{X}$ Q-Solution, $1 \mu \mathrm{l}$ each of deoxynucleotide triphosphate mix $(10 \mathrm{mM}), 0.1 \mu \mathrm{M}$ of each sense and antisense primer, and $0.5 \mu 1$ Taq DNA polymerase by using Taq DNA Polymerase kit (Qiagen, Inc.). The amplification reaction consisted of initial denaturation at $94^{\circ} \mathrm{C}$ for $3 \mathrm{~min}$, followed by three-step cycling that consisted of denaturation at $94^{\circ} \mathrm{C}$ for $30 \mathrm{sec}$, annealing at a temperature optimized for each primer pair for $30 \mathrm{sec}$ and extension at $72^{\circ} \mathrm{C}$ for 1 min for 30 cycles (optimal number of cycles determined prior to the experiment). A final extension step was performed at $72^{\circ} \mathrm{C}$ for $10 \mathrm{~min}$. The $150 \mathrm{ng}$ amplification products were electrophoresed on $2 \%$ agarose gels and visualized by ethidium bromide staining. The results were normalized to the mRNA level of $\beta$-actin, a housekeeping enzyme. These experiments were performed using samples from at least five different cell preparations and quantification (BioSens Gel Documentation System, Shanghai Bio-Tech Co., Ltd., Shanghai, China) of mRNA was confirmed using the same cell sample at least in triplicate.

Reporter gene assay. Cells were switched to media containing $0.5 \% \mathrm{FBS}$ and $1 \%$ penicillin/streptomycin and transfected using FuGENE 3 transfection reagent (Roche Diagnostics, Indianapolis, IN, USA) $500 \mu 1$ TOPflash (wild-type TCF) or FOPflash (mutant TCF) luciferase reporter plasmids (300 ng/ml) (Upstate Biotechnology; EMD Millipore, Billerica, MA, USA) were co-transfected into Saos- 2 cells $\left(\sim 1 \times 10^{6}\right)$ with $500 \mu \mathrm{l}$ Renilla luciferase marker plasmid (5 ng/ml) (Promega Corporation, Madison, WI, USA) at $37^{\circ} \mathrm{C}$ for $48 \mathrm{~h}$. The cells were subjected to 0 or $12 \%$ tensile stress for $1 \mathrm{~h}$. Cells were subsequently incubated for $4 \mathrm{~h}$ in $12 \mathrm{ml} \mathrm{DMEM}+0.1 \% \mathrm{FBS}$ and $1 \%$ penicillin/streptomycin, after which the cells were processed for Dual Luciferase Assays (Dual-Luciferase ${ }^{\circledR}$ Reporter Assay System; Promega Corporation). Results were calculated by standardizing to Renilla luciferase counts and subtracting the mutant (FOPflash) luciferase counts from the wild-type (TOPflash) counts.

Western blotting, immunoprecipitation and immunoblotting. Cells that were subjected to 0 or $12 \%$ tensile stress for $1 \mathrm{~h}$ were cultured on flex membranes. Following treatment, cells were washed three times with ice-cold PBS and placed on ice. Cells were lysed with $500 \mu \mathrm{l}$ ice-cold lysis buffer at $\mathrm{pH} 7.4$ (50 mM HEPES, $5 \mathrm{mM}$ EDTA and $50 \mathrm{mM} \mathrm{NaCl}$ ), $1 \%$ Triton-X-100, protease inhibitors $(10 \mu \mathrm{g} / \mathrm{ml}$ aprotinin, $1 \mathrm{mM}$ phenylmethylsulfonyl fluoride and $10 \mu \mathrm{g} / \mathrm{ml}$ leupeptin) and phosphatase inhibitors (50 mM sodium fluoride, $1 \mathrm{mM}$ sodium orthovanadate and $10 \mathrm{mM}$ sodium pyrophosphate). Solubilized proteins were centrifuged at $14,000 \mathrm{x} \mathrm{g}$ in a microfuge $\left(4^{\circ} \mathrm{C}\right)$ for $15 \mathrm{~min}$ and supernatants were stored at $-80^{\circ} \mathrm{C}$. Extracted proteins were quantified by the Bradford assay. Nuclear extract was also prepared: The cell homogenates were centrifuged at $450 \mathrm{x} \mathrm{g}$ for $5 \mathrm{~min}$ at $4^{\circ} \mathrm{C}$. The supernatant was discarded, and $200 \mu \mathrm{l}$ of hypotonic buffer containing $10 \mathrm{mM}$ HEPES, $1 \mathrm{mM}$ EDTA, $1 \mathrm{mM} \mathrm{MgCl} 2,10 \mathrm{mM} \mathrm{KCl}, 0.5 \mathrm{mM}$ DTT, $20 \mu \mathrm{g} / \mathrm{ml}$ aprotinin, $0.5 \%$ Nonidet P-40, $4 \mu \mathrm{g} / \mathrm{ml}$ leupeptin and $0.2 \mathrm{mM}$ 
A

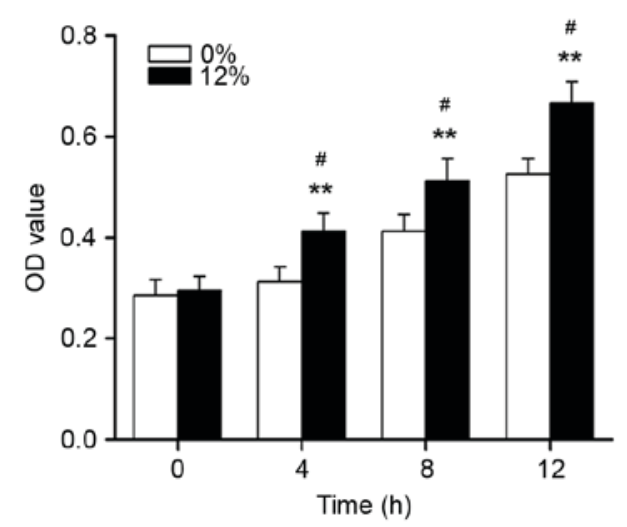

B

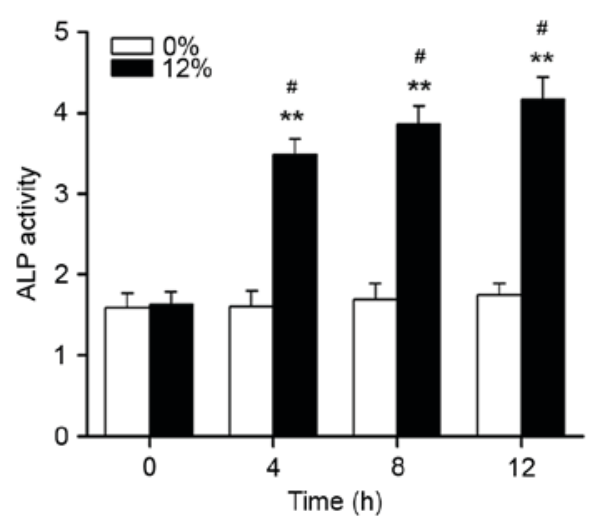

Figure 1. Cyclic tensile stress promoted the proliferation and ALP activity of Saos-2 osteoblastic cells. (A) MTT assay results for cell proliferation in cells treated with 0 or $12 \%$ tensile stress. (B) ALP activity was detected in cells treated with 0 or $12 \%$ tensile stress. ${ }^{* *} \mathrm{P}<0.01$ vs. corresponding time point in $0 \%$ tensile stress group and ${ }^{\#} \mathrm{P}<0.05$ vs. $0 \mathrm{~h}$ in $12 \%$ tensile stress group, $\mathrm{n}=6$. ALP, alkaline phosphatase; OD, optical density.

phenylmethanesulfonyl fluoride were added to the cell pellet. Following centrifugation at $7,200 \times \mathrm{g}$ for $15 \mathrm{~min}$ at $4^{\circ} \mathrm{C}$, the supernatant, which contained the membranes and the cytosolic fraction, was discarded. The pellets, consisting of crude nuclei, were suspended for $15 \mathrm{~min}$ at $4^{\circ} \mathrm{C}$ in $20 \mu \mathrm{l}$ of a hypertonic solution (20 mM HEPES, $420 \mathrm{mM} \mathrm{NaCl}, 1.5 \mathrm{mM} \mathrm{MgCl}$, $0.5 \mathrm{mM}$ DTT, $0.2 \mathrm{mM}$ PMSF, $0.2 \mathrm{mM}$ EDTA and 25\% glycerol) containing protease inhibitor. The samples were centrifuged at $16,000 \mathrm{x} g$ for $30 \mathrm{~min}$ at $4^{\circ} \mathrm{C}$. The supernatant, which contained nuclear proteins, was stored at $-80^{\circ} \mathrm{C}$ until use.

For immunoprecipitation, 600-700 $\mu \mathrm{g} / \mu \mathrm{l}$ cell lysates were incubated with E-cadherin (1:200; sc-9988; Santa Cruz Biotechnology, Inc.) or $\beta$-catenin (1:200; sc-7199; Santa Cruz Biotechnology, Inc.) antibodies overnight at $4^{\circ} \mathrm{C}$ and subsequently incubated with $25 \mathrm{ml}$ protein $\mathrm{A}-\mathrm{G}$ agarose beads (Beyotime Institute of Biotechnology, Shanghai, China) for $1 \mathrm{~h}$ at $4^{\circ} \mathrm{C}$ with gentle rocking. The beads were washed four times with $500 \mathrm{ml}$ lysis buffer and proteins were solubilized in Laemmli sample buffer (sc-286962; Santa Cruz Biotechnology, Inc.) containing 2-mercaptoethanol. Immunoprecipitated samples or samples prepared directly after cell lysis were separated using 10\% SDS-PAGE and transferred onto nitrocellulose membranes. The amount of protein was $70 \mu \mathrm{g}$ per lane. Membranes were blocked overnight at $4^{\circ} \mathrm{C}$ with PBS containing $5 \%$ non-fat dry milk and $0.1 \%$ Tween-20. The blots were incubated overnight at $4^{\circ} \mathrm{C}$ with primary antibodies against phosphorylated (p)-GSK-3 $\beta$ (1:100; sc-373800), GSK-3 $\beta$ (1:100; sc-377213; both Santa Cruz Biotechnology, Inc.), $\beta$-actin (1:4,000; A2228; Sigma, St. Louis, MO, USA), $\beta$-catenin (1:100; sc-7199), lamin B $(1: 100 ; 374015)$ and E-cadherin $(1: 100$; sc-9988; all Santa Cruz Biotechnology, Inc.) in PBS containing $1 \%$ non-fat dry milk and $0.1 \%$ Tween-20. Following incubation with secondary antibodies (1:2,000; 7074 and 7076; anti-rabbit or anti-mouse IgG antibody conjugated to horseradish peroxidase; Cell Signaling Technology; Danvers, MA, USA) for $1 \mathrm{~h}$ at $37^{\circ} \mathrm{C}$ in PBS containing $1 \%$ non-fat dry milk and $0.1 \%$ Tween-20, proteins were detected by chemiluminescence (SuperSignal $^{\mathrm{TM}}$ West Femto Trial kit; Thermo Fisher Scientific, Inc.). and protein expression were analysed by Bandscan version 5.0 software (Glyko, Inc., Novato, CA, USA).

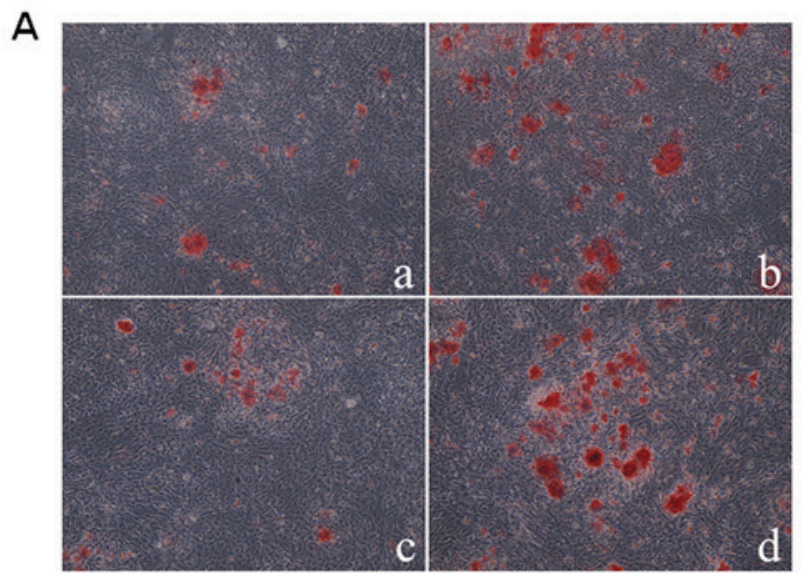

B

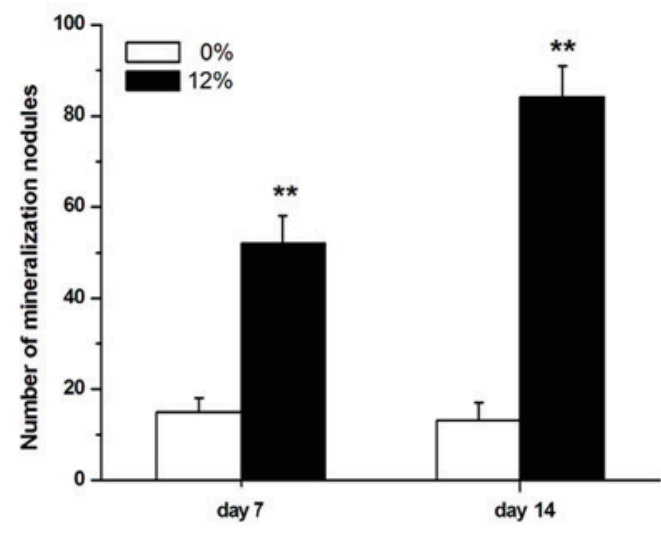

Figure 2. Mineralization nodule formation was increased in Saos-2 osteoblastic cells induced by $12 \%$ tensile stress. (A) Mineralization nodules were detected by using Alizarin Red S staining. (a) Saos-2 cells after 7 days without tensile stress. (b) Saos- 2 cells after 7 days with $12 \%$ tensile stress. (c) Saos-2 cells after 14 days without tensile stress. (d) Saos-2 cells after 14 days with $12 \%$ tensile stress. Magnification, x40. (B) Quantified results for mineralization nodules. ${ }^{* *} \mathrm{P}<0.01$ vs. corresponding results in $0 \%$ tensile stress group, $\mathrm{n}=10$.

Statistical analysis. Data are presented as the mean \pm standard deviation. Statistical analysis was processed by SPSS version 16.0 (SPSS, Inc., Chicago, IL, USA). Data in Fig. 1 were subjected to repeated analysis of variance and multiple 


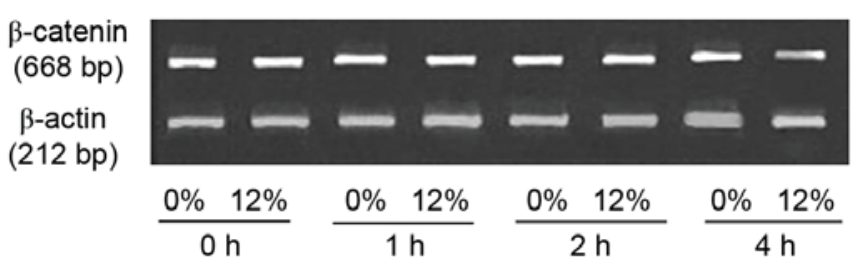

Figure 3. Agarose gel electrophoresis of the products of reverse transcription-polymerase chain reaction using specific primers for $\beta$-catenin and $\beta$-actin. No difference in the expression of $\beta$-catenin mRNA was observed between the 0 and $12 \%$ tensile stress groups at different time points.
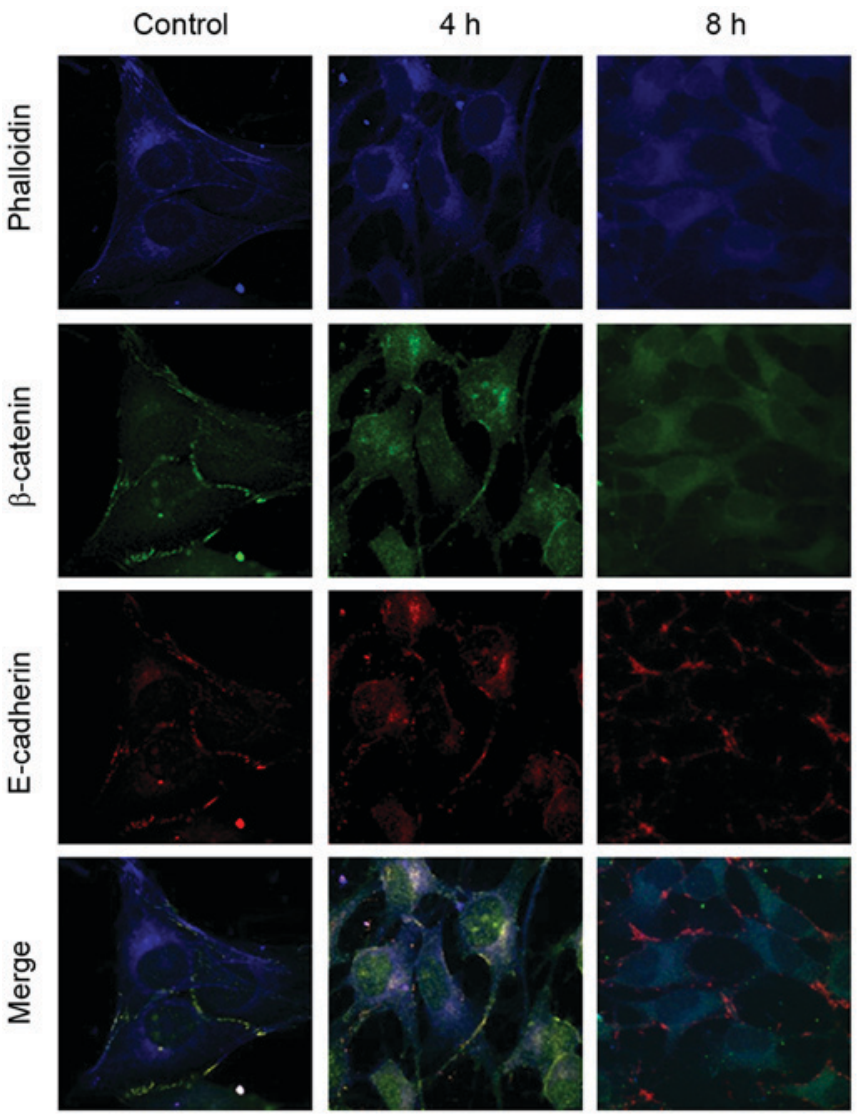

Figure 4. Immunofluorescence analysis of $\beta$-catenin and E-cadherin in Saos- 2 osteoblastic cells following tensile stress. $\beta$-catenin was localized on the cytomembrane in the control group and in the cytoplasm and nucleus after 4 or $8 \mathrm{~h}$ of $12 \%$ tensile stress. However, E-cadherin was distributed on the cytomembrane throughout. Magnification, x600.

comparisons were made by Tukey's method. Student's t-test was used to analyze differences between two groups. $\mathrm{P}<0.05$ was considered to indicate a statistically significant difference.

\section{Results}

The effects of cyclic tensile strain on proliferation, ALP activity and mineralization nodule formation in Saos-2 osteoblastic cells. As demonstrated in Fig. 1, the proliferation and ALP activity of Saos-2 osteoblastic cells were significantly increased following mechanical strain treatment at 4, 8 and $12 \mathrm{~h}(\mathrm{P}<0.01)$. The formation of mineralization nodules in Saos-2 osteoblastic cells was also promoted by a $12 \%$ mechanical strain elongation rate, compared with unstrained cells $(\mathrm{P}<0.01$; Fig. 2$)$.
The effects of cyclic tensile strain application on $\beta$-catenin expression in Saos- 2 cells. The expression level of $\beta$-catenin mRNA was measured using RT-PCR (Fig. 3). No marked differences in the expression level of $\beta$-catenin mRNA were observed between the 0 and $12 \%$ tensile stress groups. The immunofluorescent staining results demonstrated that $\beta$-catenin and E-cadherin were detected prior to (control; Fig. 4) and following (4 and $8 \mathrm{~h}$; Fig. 4) $12 \%$ tensile stress. $\beta$-catenin was localized primarily on the cytomembrane prior to stress, while it was observed in the cytoplasm and nucleus following stress. However, E-cadherin remained on the cytomembrane throughout. Co-localization of $\beta$-catenin and E-cadherin was observed prior to stress; however, co-localization was not observed following $12 \%$ tensile stress for $8 \mathrm{~h}$ (Fig. 4).

GSK-3 $\beta$ phosphorylates $\beta$-catenin and subsequently facilitates the degradation of $\beta$-catenin. The present study further investigated whether mechanical strain influences GSK-3 $\beta$ activity (Fig. 5). The results demonstrated that $12 \%$ tensile strain increased the cytosolic phosphorylation of GSK-3 $\beta$ expression, while it had no effect on GSK-3 $\beta$ levels. In addition, nuclear $\beta$-catenin levels were upregulated by tensile stress.

The effects of cyclic tensile strain application on TCF reporter gene activity. In the current study, TCF reporter gene transcriptional activity was also determined in Saos-2 cells, and the results demonstrated a significant increase in TCF reporter gene activity compared with the control group following $12 \%$ tensile for $1 \mathrm{~h}(\mathrm{P}<0.05$; Fig. 6$)$. Therefore, the Wnt/ $\beta$-catenin pathway may be functionally activated under tensile stress.

The effects of cyclic tensile strain application on $m R N A$ expression of genes downstream of the Wnt/ $\beta$-catenin pathway. The mRNA expression of downstream genes (COX-2, c-fos, c-Jun and cyclin D1) of the Wnt/ $\beta$-catenin pathway was investigated by RT-PCR following 0 or $12 \%$ tensile stress for $4 \mathrm{~h}$ (Fig. 7). The results demonstrated a significant increase in the mRNA transcript levels of these genes in the $12 \%$ tensile stress group compared with the control group ( $\mathrm{P}<0.01$; Fig. 7).

The effects of cyclic tensile strain application on binding of the $\beta$-catenin/E-cadherin complex. Immunoprecipitation was performed to observe the effects of tensile stress on the binding of the $\beta$-catenin/E-cadherin complex (Fig. 8). Immunoblot assays demonstrated that $\beta$-catenin and $\mathrm{E}$-cadherin protein levels in the experimental groups were unchanged following $12 \%$ tensile stress for $1 \mathrm{~h}$. However, immunoprecipitation assays demonstrated a significant decrease in the binding of $\beta$-catenin to E-cadherin.

\section{Discussion}

Numerous in vitro and in vivo experiments have reported that mechanical loading promoted osteoblast proliferation and increased the transcription of various bone-associated genes (4-6). However, the molecular mechanism by which mechanical signals are transduced in osteoblasts remains unclear. Previous studies have indicated that the integrin/focal 
A

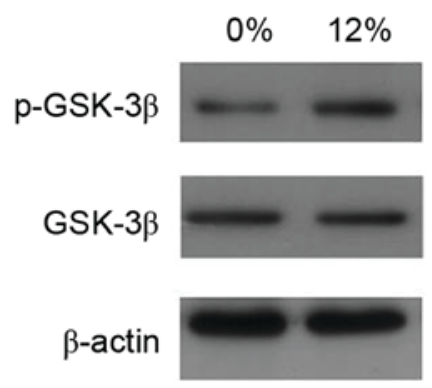

B

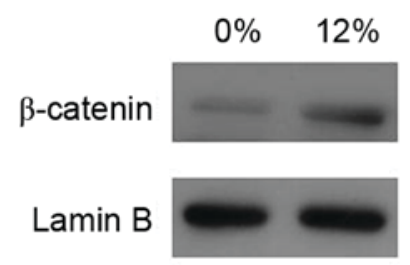

Figure 5. Effect of tensile stress on protein expression in Saos-2 cells. (A) p-GSK-3 $\beta$ and GSK-3 $\beta$ protein expression in cytosolic fractions was determined by western blot analysis following $1 \mathrm{~h}$ of 0 or $12 \%$ tensile stress. (B) Expression level of nuclear $\beta$-catenin protein was determined by western blot analysis following $1 \mathrm{~h}$ of 0 or $12 \%$ tensile stress. p-, phosphorylated; GSK, glycogen synthase kinase.

adhesion kinase pathway and calcium ion channels are involved in the signal transduction process $(21,22)$. Robinson et al $(23)$ demonstrated that target gene expression in the Wnt $/ \beta$-catenin pathway was upregulated by the application of a four-point bending load to the long bones of low-density lipoprotein receptor related protein (Lrp) 5 transgenic mice, indicating that mechanical loading may activate the $\mathrm{Wnt} / \beta$-catenin signaling pathway.

The Wnt/ $\beta$-catenin signaling pathway has become a major research focus in developmental biology. Mammalian Wnt proteins bind to the receptor complex of the Lrp5/Lrp6 extracellular region and the Frizzled receptor. Subsequently, through a series of cytoplasmic protein interactions, $\beta$-catenin accumulates in the cytoplasm, translocates to the nucleus and functions with transcription factors, TCF and LEF-1, to activate bone-associated target gene transcription. This pathway is referred to as the classical $\mathrm{Wnt} / \beta$-catenin pathway, and it has an important role in bone formation $(24,25)$. Loss-of-function mutations in Lrp5 resulted in osteoblast dysfunction and subsequent osteoporosis (25). Furthermore, Boyden et al (26) demonstrated that a mutation at position 171 in the Lrp5 protein led to the total loss of dickkopf Wnt signaling pathway inhibitor 1 antagonism in the Wnt signaling pathway in vitro, which resulted in in bone sclerosis. In addition, Bain et al (10) reported that increased expression and activity of the early osteoblast differentiation marker ALP was induced when $\beta$-catenin was overexpressed in C3H1OT1/2 cells or when lithium chloride was added to enhance the expression of endogenous $\beta$-catenin. These previous reports indicated that $\beta$-catenin has an important role in the proliferation and differentiation of osteoblast precursor cells and osteoblasts. The present study applied $12 \%$ cyclical tensile stress to osteoblasts and also demonstrated that the proliferation, ALP activity and mineralization nodule formation of Saos-2 osteoblastic cells were promoted. Subsequently, the present study investigated the alterations in the $\mathrm{Wnt} / \beta$-catenin signaling pathway following tensile stress application in osteoblasts in vitro.

Previous studies have demonstrated that intracellular $\beta$-catenin serves a dual function in cell-cell adhesion structures and as a regulation factor of downstream gene expression. Under normal circumstances, $\beta$-catenin forms a complex with cadherins in the cell membrane, while free $\beta$-catenin is rapidly degraded via phosphorylation by the complex of GSK-3 $\beta$, axin and adenomatous polyposis coli in the cytoplasm.

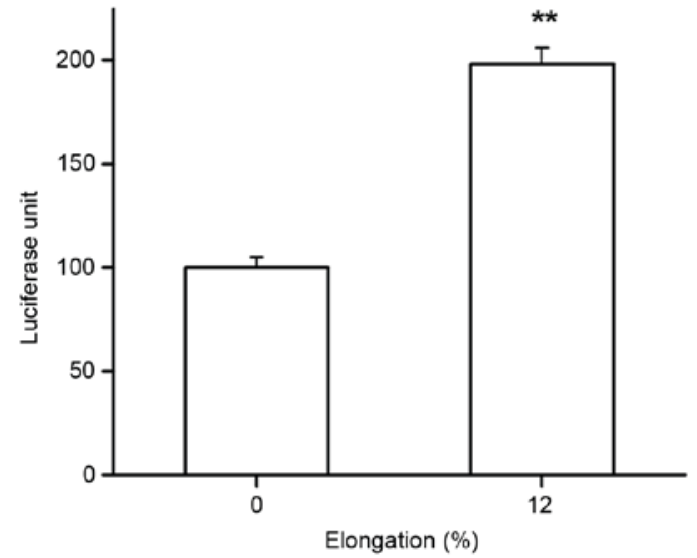

Figure 6. TCF reporter gene was activated by cyclic tensile strain in Saos-2 cells. Reporter activity was normalized by Renilla luciferase activity and mutant TCF luciferase activity was subtracted from wild-type TCF luciferase activity. Application of $12 \%$ tensile stress induced a significant two-fold increase in TCF reporter gene activity compared with the $0 \%$ tensile stress group. ${ }^{* *} \mathrm{P}<0.01$ vs. $0 \%$ tensile stress group, $\mathrm{n}=6$. TCF, T-cell factor; elongation, tensile stress.

However, if GSK-3 $\beta$ becomes inactivated by phosphorylation, $\beta$-catenin is not degraded. As a result, $\beta$-catenin accumulates in the cytoplasm and triggers signal transduction, followed by translocation into the nucleus to promote target gene transcription by binding to transcription factors. Therefore, the nuclear translocation of $\beta$-catenin into is a prerequisite for the activation of the classical Wnt/ $\beta$-catenin pathway $(13,27)$. The present study demonstrated that the phosphorylation of GSK-3 $\beta$ and nuclear $\beta$-catenin expression was significantly enhanced following tensile stress. Nuclear $\beta$-catenin was more apparent in the 4 and $8 \mathrm{~h}$ tensile stress groups compared with the control group. These results indicated that $12 \%$ cyclical tensile stress altered the localization of $\beta$-catenin in the cell, which may trigger $\beta$-catenin-mediated Wnt signal transduction and maintain the activation of this signaling pathway for an extended period of time. Furthermore, $\beta$-catenin mRNA and protein expression levels were also measured in the current study, however, no marked differences between the experimental and control groups were observed, indicating that tensile stress did not increase the level of $\beta$-catenin transcription or its protein synthesis. Instead, tensile stress primarily resulted in alterations in the spatial localization of 
A

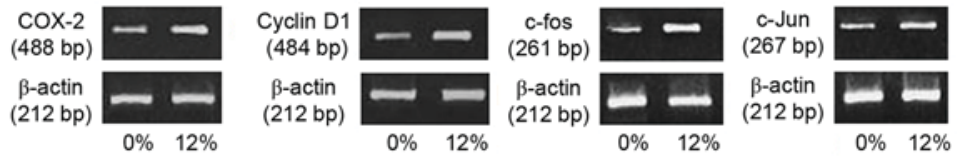

B

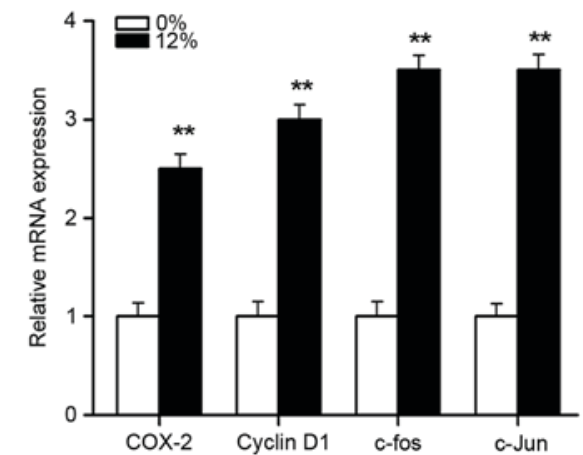

Figure 7. Gene expression of downstream targets of the Wnt/ $\beta$-catenin signaling pathway in Saos-2 osteoblastic cells following tensile stress. (A) Gene expression was measured by reverse transcription-polymerase chain reaction following 0 or $12 \%$ cyclic tensile stress. (B) Quantified gene expression levels obtained from quantitative densitometric analysis. ${ }^{* *} \mathrm{P}<0.01$ vs. $0 \%$ tensile stress group, $\mathrm{n}=6 . \mathrm{COX}$, cyclooxygenase.

A

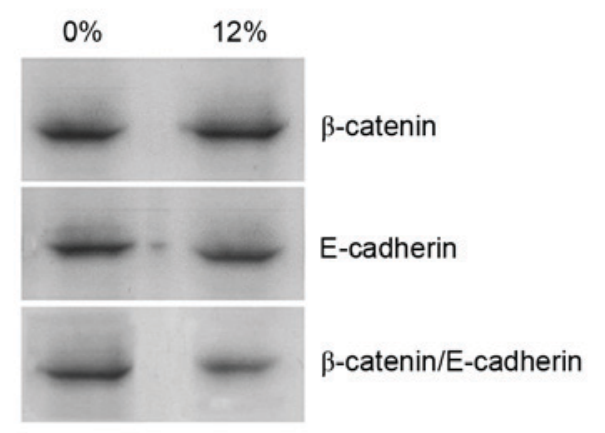

B

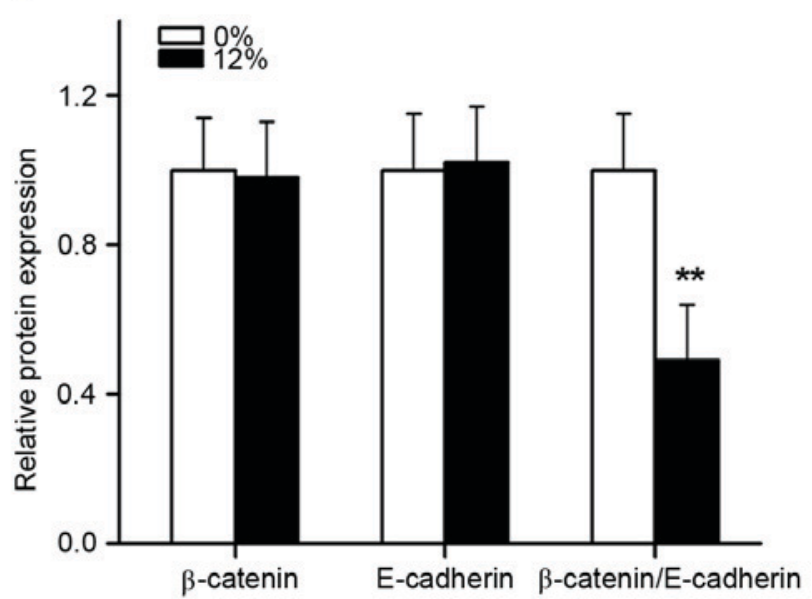

Figure 8. The effects of cyclic tensile stress on the association of total $\beta$-catenin with E-cadherin. (A) Immunoprecipitation analysis demonstrated a marked decrease in the binding of $\beta$-catenin to E-cadherin after $12 \%$ tensile stress was applied to the cells for $1 \mathrm{~h}$. (B) Results were quantified by densitometric analysis and statistically analyzed. ${ }^{* *} \mathrm{P}<0.01$ vs. $0 \%$ tensile stress group, $\mathrm{n}=6$.

$\beta$-catenin and promoted its translocation into the nucleus. In the current study, $12 \%$ tensile stress was selected as this value falls within the tolerable physiological range for bone. In the study by Norvell et al (28), $\beta$-catenin nuclear translocation was observed in primary rat osteoblasts after a 10 dynes $/ \mathrm{cm}^{2}$ fluid shear stress was applied, and this translocation was maintained at a relatively high level up to $6 \mathrm{~h}$ after loading. Furthermore, it was reported by Case et al (29) that transient nuclear translocation of $\beta$-catenin occurred in CIMC- 4 cells after a $2 \%$ stretch force was applied, however, this event was decreased at $1 \mathrm{~h}$. The difference between these results may be attributed to the different loading systems, force values and cell types used.

In the present study, the results also demonstrated that, following transfection of the TCF reporter gene into osteoblasts, the activity of the nuclear transcription factor
TCF was significantly enhanced following a $12 \%$ cyclical stretch. The TCF/LEF family is a well-defined group of Wnt/ $\beta$-catenin downstream target molecules. Unlike other traditional transcription factors, $\mathrm{TCF} / \mathrm{LEF}$ cannot activate transcription alone. Instead, they rely on the binding and activation of $\beta$-catenin. TCF/LEF mutually bind to transcription inhibitors, when the $\mathrm{Wnt} / \beta$-catenin pathway remains inactive. However, upon activation of the pathway, nuclear $\beta$-catenin facilitates $\mathrm{Wnt} / \beta$-catenin target gene expression by replacing the inhibitory factors and binding to the $\mathrm{N}$-terminal region of $\mathrm{TCF} / \mathrm{LEF}$ to enhance its interaction with chromatin and restore transcriptional activity. In the study by Chou et al (30), impaired bone formation was observed in TCF-4 deficient mice, indicating that the activation and expression of this gene is closely associated with bone formation. The results of the TCF luciferase reporter 
gene assay in the present study were consistent with the immunofluorescence results, which demonstrated nuclear localization of $\beta$-catenin following $12 \%$ tensile stress. Together, these results demonstrate that nuclear translocation and activation of $\beta$-catenin due to stretching may further enhance the transcriptional activity of TCF and lead to the functional activation of the $\mathrm{Wnt} / \beta$-catenin signaling pathway.

To further confirm and observe the activation of the Wnt/ $\beta$-catenin signaling pathway following stretch loading, the present study investigated the expression of downstream target genes, including COX-2, c-fos, c-Jun and cyclin D1. The mRNA transcript levels of COX-2, c-fos, c-Jun and cyclin D1 were significantly enhanced after $4 \mathrm{~h}$ stretch loading, as revealed by RT-PCR analysis. Norvell et al (28) reported that the expression of COX-2 was enhanced by the activation of the Wnt $/ \beta$-catenin pathway by GSK-3 $\beta$ inhibitors. Additionally, the function of COX-2 in bone tissue reconstruction following force loading was also confirmed. This indicated that COX-2 is an important target gene in the $\mathrm{Wnt} / \beta$-catenin pathway and its expression may be triggered by the activation of the Wnt/ $\beta$-catenin pathway by tensile stress. Robinson et al (23) reported that, after Lrp5 G171V transgenic mice were treated with a GSK-3 $\beta$ inhibitor or stress loading, the expression of the Wnt/ $\beta$-catenin target genes, including $\mathrm{c}$-fos, c-Jun and cyclin D1, in the two groups was higher compared with the control, although no significant differences were observed between the two experimental groups. This is consistent with the present study's experimental results from cells after stretch loading in vitro. Together, these results indicate that stretch loading may activate the $\mathrm{Wnt} / \beta$-catenin pathway and trigger the expression of downstream target genes that are closely associated with bone formation.

In addition, the current study investigated the mechanism by which tensile stress activated the Wnt/ $\beta$-catenin signaling pathway in osteoblasts. Previous studies have demonstrated that mechanical loading promote osteoblast proliferation and differentiation $(4,5,31)$, however, the mechanism by which osteoblasts convert stimulating mechanical signals to biochemical signals is unknown. The results of the current study demonstrated that the levels of $\beta$-catenin and E-cadherin were not significantly altered, however, the binding level of $\beta$-catenin with E-cadherin was significantly reduced following tensile stress. It is established that cadherins are a cell-cell adhesion mediation and signal transduction family, and they are comprised of three different types, including $\mathrm{E}$-cadherin, $\mathrm{N}$-cadherin and $\mathrm{P}$-cadherin, that are differentially distributed in different tissues. The cytoplasmic region of cadherin molecules is highly conserved and is connected to the cytoskeleton. Acting as a transmembrane calcium-dependent adhesion molecule in various cell types, including osteoblasts, it binds directly to $\beta$-catenin and forms a complex in the cell membrane, restricting $\beta$-catenin to the cell membrane and preventing it from translocating into the nucleus to function in the regulation of downstream gene expression. Adkison et al (32) demonstrated that the amount of vascular endothelial cadherin binding to $\beta$-catenin was significantly reduced after $34 \%$ stretch loading was applied to mouse pulmonary artery endothelial cells for $24 \mathrm{~h}$. In addition, the present study demonstrated that the binding level of E-cadherin with $\beta$-catenin was significantly reduced and the amount of $\beta$-catenin that translocated into the nucleus was increased after $12 \%$ tensile stress in osteoblasts for $1 \mathrm{~h}$. Therefore, we hypothesize that this may be due to the structural deformation of the cell membrane and cytoskeleton under tensile stress, which disrupts the $\beta$-catenin and E-cadherin complex and causes the release of $\beta$-catenin from the complex. As a result, $\beta$-catenin accumulates in the cytoplasm and translocates into the nucleus. This is followed by binding to and activation of the nuclear transcription factor TCF to promote the expression of the downstream bone formation-associated target genes COX-2, c-fos, c-Jun and cyclin D1, thus facilitating the conversion of mechanical stimuli to chemical signals.

In conclusion, the results of the current study demonstrated that $12 \%$ tensile stress activated the $\mathrm{Wnt} / \beta$-catenin signaling pathway and promoted the expression of downstream target genes, including COX-2, c-fos, c-Jun and cyclin D1, and that $\beta$-catenin had a pivotal role in this process. The disassociation of the $\beta$-catenin/E-cadherin complex in the osteoblast membrane under stretch loading and the subsequent translocation of $\beta$-catenin into the nucleus may be an intrinsic mechanical signal transduction mechanism. Together, these observations provide novel insight in order to obtain a deeper understanding of the molecular mechanisms of mechanical signal transduction and bone reconstruction.

\section{Acknowledgements}

Not applicable.

\section{Funding}

The present study was supported by the National Natural Science Foundation of China (grant nos. 31070836 and 31200706).

\section{Availability of data and materials}

The datasets used and/or analyzed during the current study are available from the corresponding author on reasonable request.

\section{Authors' contributions}

FFL was mainly responsible for the design of the experiment, cell culture, statistical analysis and the writing of the article. BZ was responsible for the MTT, immunofluorescence and ALP assays. JHC was responsible for RT-PCR, reporter gene assay, western blot analysis and immunoprecipitation. FLC was responsible for the design of the experiment and revising the paper. YD and XF were responsible for the design of the experiment.

\section{Ethics approval and consent to participate}

Not applicable.

\section{Consent for publication}

Not applicable. 


\section{Competing interests}

The authors declare that there are no competing interests.

\section{References}

1. Karlsson MK, Johnell O and Obrant KJ: Is bone mineral density advantage maintained long-term in previous weight lifters? Calcif Tissue Int 57: 325-328, 1995.

2. Lemaire T, Capiez-Lernout E, Kaiser J, Naili S and Sansalone V: What is the importance of multiphysical phenomena in bone remodelling signals expression? A multiscale perspective. J Mech Behav Biomed Mater 4: 909-920, 2011.

3. Kim JY, Kim BI, Jue SS, Park JH and Shin JW: Localization of osteopontin and osterix in periodontal tissue during orthodontic tooth movement in rats. Angle Orthod 82: 107-114, 2012.

4. Eriksen EF: Cellular mechanisms of bone remodeling. Rev Endocr Metab Disord 11: 219-227, 2010.

5. Wallace JM, Rajachar RM, Allen MR, Bloomfield SA, Robey PG, Young MF and Kohn DH: Exercise-induced changes in the cortical bone of growing mice are bone-and gender-specific. Bone 40: 1120-1127, 2007.

6. Liedert A, Kaspar D, Blakytny R, Claes L and Ignatius A: Signal transduction pathways involved in mechanotransduction in bone cells. Biochem Biophys Res Commun 349: 1-5, 2006.

7. Rawadi G, Vayssière B, Dunn F, Baron R and Roman-Roman S: BMP-2 controls alkaline phosphatase expression and osteoblast mineralization by a Wnt autocrine loop. J Bone Miner Res 18 $1842-1853,2003$.

8. Jackson A, Vayssière B, Garcia T, Newell W, Baron R, Roman-Roman S and Rawadi G: Gene array analysis of Wnt-regulated genes in C3H10T1/2 cells. Bone 36: 585-598, 2005.

9. Caetano-Lopes J, Canhão H and Fonseca JE: Osteoblasts and bone formation. Acta Reumatol Port 32: 103-110, 2007.

10. Bain G, Müller T, Wang X and Papkoff J: Activated beta-catenin induces osteoblast differentiation of $\mathrm{C} 3 \mathrm{H} 10 \mathrm{~T} 1 / 2$ cells and participates in BMP2 mediated signal transduction. Biochem Biophys Res Commun 301: 84-91, 2003.

11. Gottardi CJ and Gumbiner BM: Adhesion signaling: How beta-catenin interacts with its partners. Curr Biol 11: R792-R794, 2001.

12. Nelson WJ and Nusse R: Convergence of Wnt, beta-catenin, and cadherin pathways. Science 303: 1483-1487, 2004.

13. Jamora $\mathrm{C}$ and Fuchs E: Intercellular adhesion, signalling and the cytoskeleton. Nat Cell Biol 4: E101-E108, 2002.

14. Smith E and Frenkel B: Glucocorticoids inhibit the transcriptional activity of LEF/TCF in differentiating osteoblasts in a glycogen synthase kinase-3beta-dependent and -independent manner. J Biol Chem 280: 2388-2394, 2005.

15. Sakamoto I, Kishida S, Fukui A, Kishida M, Yamamoto $H$ Hino S, Michiue T, Takada S, Asashima M and Kikuchi A: A novel beta-catenin-binding protein inhibits beta-catenin-dependent Tcf activation and axis formation. J Biol Chem 275 32871-32878, 2000

16. Kulkarni NH, Onyia JE, Zeng Q, Tian X, Liu M, Halladay DL, Frolik CA, Engler T, Wei T, Kriauciunas A, et al: Orally bioavailable GSK-3alpha/beta dual inhibitor increases markers of cellular differentiation in vitro and bone mass in vivo. J Bone Miner Res 21: 910-920, 2006.

17. Kato M, Patel MS, Levasseur R, Lobov I, Chang BH, Glass DA II, Hartmann C, Li L, Hwang TH, Brayton CF, et al: Cbfa1-independent decrease in osteoblast proliferation, osteopenia, and persistent embryonic eye vascularization in mice deficient in Lrp5, a Wnt coreceptor. J Cell Biol 157: 303-314, 2002 .
18. Vaes BL, Dechering KJ, van Someren EP, Hendriks JM, van de Ven CJ, Feijen A, Mummery CL, Reinders MJ, Olijve W, van Zoelen EJ and Steegenga WT: Microarray analysis reveals expression regulation of Wnt antagonists in differentiating osteoblasts. Bone 36: 803-811, 2005.

19. Glass DA II and Karsenty G: Molecular bases of the regulation of bone remodeling by the canonical Wnt signaling pathway. Curr Top Dev Biol 73: 43-84, 2006.

20. Reyes L, Eiler-McManis E, Rodrigues PH, Chadda AS, Wallet SM, Bélanger M, Barrett AG, Alvarez S, Akin D, Dunn WA Jr and Progulske-Fox A: Deletion of lipoprotein PG0717 in Porphyromonas gingivalis W83 reduces gingipain activity and alters trafficking in and response by host cells. PLoS One 8: e74230, 2013.

21. Yan Y, Sun H, Gong Y, Yan Z, Zhang X, Guo Y and Wang Y: Mechanical strain promotes osteoblastic differentiation through integrin- $\beta 1$-mediated $\beta$-catenin signaling. Int $\mathbf{J}$ Mol Med 38: 594-600, 2016

22. Wang H, Sun W, Ma J, Pan Y, Wang L and Zhang W: Polycystin-1 mediates mechanical strain-induced osteoblastic mechanoresponses via potentiation of intracellular calcium and Akt/ $\beta$-catenin pathway. PLoS One 9: e91730, 2014.

23. Robinson JA, Chatterjee-Kishore M, Yaworsky PJ, Cullen DM, Zhao W, Li C, Kharode Y, Sauter L, Babij P, Brown EL, et al: Wnt/beta-catenin signaling is a normal physiological response to mechanical loading in bone. J Biol Chem 281: 31720-31728, 2006.

24. Manolagas SC and Almeida M: Gone with the Wnts: Beta-catenin, $\mathrm{T}$-cell factor, forkhead box $\mathrm{O}$, and oxidative stress in age-dependent diseases of bone, lipid, and glucose metabolism. Mol Endocrinol 21: 2605-2614, 2007.

25. Zhao C, Li Y, Wang X, Zou S, Hu J and Luo E: The effect of uniaxial mechanical stretch on Wnt/ $\beta$-catenin pathway in bone mesenchymal stem cells. J Craniofac Surg 28: 113-117, 2017.

26. Boyden LM, Mao J, Belsky J, Mitzner L, Farhi A, Mitnick MA, Wu D, Insogna K and Lifton RP: High bone density due to a mutation in LDL-receptor-related protein 5. N Engl J Med 346: 1513-1521, 2002

27. Roura S, Miravet S, Piedra J, García de Herreros A and Duñach M: Regulation of E-cadherin/Catenin association by tyrosine phosphorylation. J Biol Chem 274: 36734-36740, 1999.

28. Norvell SM, Alvarez M, Bidwell JP and Pavalko FM: Fluid shear stress induces beta-catenin signaling in osteoblasts. Calcif Tissue Int 75: 396-404, 2004

29. Case N, Ma M, Sen B, Xie Z, Gross TS and Rubin J: Beta-catenin levels influence rapid mechanical responses in osteoblasts. J Biol Chem 283: 29196-29205, 2008.

30. Chou HY, Howng SL, Cheng TS, Hsiao YL, Lieu AS, Loh JK, Hwang SL, Lin CC, Hsu CM, Wang C, et al: GSKIP is homologous to the Axin GSK3beta interaction domain and functions as a negative regulator of GSK3 beta. Biochemistry 45: 11379-11389, 2006.

31. Brady RT, O'Brien FJ and Hoey DA: Mechanically stimulated bone cells secrete paracrine factors that regulate osteoprogenitor recruitment, proliferation, and differentiation. Biochem Biophys Res Commun 459: 118-123, 2015.

32. Adkison JB, Miller GT, Weber DS, Miyahara T, Ballard ST, Frost JR and Parker JC: Differential responses of pulmonary endothelial phenotypes to cyclical stretch. Microvasc Res 71: 175-184, 2006.

This work is licensed under a Creative Commons Attribution-NonCommercial-NoDerivatives 4.0 International (CC BY-NC-ND 4.0) License. 